\title{
Discourse on Democracy in the July 22, 2011 General Election Political Campaign in Turkey: The Case of Tayyip Erdoğan's Political Rally Speeches
}

\author{
Kenan Demirci \\ Faculty of CommunicationDepartmant of Public Relations \\ Ankara University \\ kdemirci06@gmail.com
}

Doi:10.5901/ajis.2013.v2n9p13

\begin{abstract}
This study is an examination of the discourse concerning democracy in Turkey by the Turkish ruling party's political leader, Tayyip Erdoğan.It is an approach to political campaign analysis by focusing on political campaign techniques and their relationship with democratic culture. This is an attempt to investigate democratic discourse concerning political campaigns because I assume that leaders share their ideas concerning politics and democracy extensively during campaigns. If we define liberal democracy as a process of representation, then political campaigns are very important in the overall democratic structure. However, liberal democracy cannot be viewed as elections only. There are three important normative principles in liberal democracy:limited state, rule of law, and accountability. I analyse these three principles in the political rally speeches of Tayyip Erdoğan in the 2011 general elections in Turkey for the month before the elections by employing discourse analysis. As a result, we can see that the rights of the citizens are seen only as voting and the duty of the state is defined as protecting and shaping them in the speeches. Hence, we can say that the democratic discourse of Tayyip Erdogan is not sufficiently suitable for the normative principles of liberal democracy.
\end{abstract}

Keywords: Political Campaigns, Liberal Democracy, Democracy Discourse

\section{Introduction}

Liberal democracy spread in Western Europe after the 1950s and across the world after the cold war. Tens of countries have attempted to establish new democratic institutions. Elections were seen as the most important institutions in these countries. We can explain this situation as part of the general tendency of liberal democracy. Many scholars of liberal democracy believe that elections are the basic tool of the democratic process (Dahl, 2001; Lipset, 1981; Sartori, 1996). For them, liberal democracy is a system in which political elites struggle for power and elections are a basic tool to accomplish this. The role of citizens is restricted to voting. They can become informed during the election campaign and are able to decide freely. Political campaign techniques have improved to the point of realizing that citizens are increasingly well informed.

Since the 1990s, being seen as democratic is an international necessity for a country in a globalized world. If regular and frequent elections take place in a country, that country is considered democratic. Hence, in parallel to the USA and Western Europe, elections and political campaigns are seen as a necessity all over the world. This situation led to the importation of sophisticated campaign techniques. Turkey imported these campaign techniques by the 1990s. As with the other countries, elections are seen as a necessity by a democratic regime in Turkey. Özbudun described Turkey and other countries as "electoral democracies" (Özbudun, 2011).

In Turkey, democracy is seen as a tool to accomplish political objectives and concepts of democracy are very commonly used. As Dryzek and Holmes (2002) noted, "Political actors in these societies often justify their projects and preferred political orders in the language of democracy". In this process, the media create a reality and define the contents of the concepts along with the political actors. Thus, it is very important to analyse democratic discourse in political campaigns to understand the approach of political elites to democracy. We can only define a country as a democracy if it has all of the institutions of democracy (Dahl, 2001, p. 105), not just elections. Turkey provides a very thought-provoking model and this study is intended to understand democratic discourse in Turkey using the case of the 2011 general elections. For that purpose, first, I describe the normative principles of democracy to compare the discourse of political elites in Turkey. Second, I discuss the elements of a modern political campaign process. Last, I analyse the Tayyip Erdoğan's discourse of democracy in the 2011 general elections in Turkey. 


\subsection{Liberal Democracy and Its Normative Principles}

As I mentioned above, liberal democracy is a system that regulates the relation between political elites and masses. In this model, the role of the citizen is voting and the role of political elites is settling political issues. In this sample process to protect the citizens and prevent excessive strengthening of the State, scholars of liberal democracy espouse normative principles. We can list these principles in three headings and say that these principles are the basis of democracy.

Table 1. Normative principles

\begin{tabular}{ll}
\hline Normative Principles & The content of principles \\
\hline Limited state & $\begin{array}{l}\text { Separation of law, protection of public interest, and distinction } \\
\text { between private and public sphere }\end{array}$ \\
Rule of law & $\begin{array}{l}\text { Personal rights, political rights, and economic rights } \\
\text { Accountability }\end{array}$ \\
$\begin{array}{l}\text { Free and frequent elections, horizontal accountability mechanism, } \\
\text { and intervention of organised interests. }\end{array}$ \\
\hline
\end{tabular}

Note. The information in the table is based on Offe (2011) and Beetham (1996).

Elections are a basic tool to accede but there are three headings to inspect the politics of power during the period between two elections. The first principle, shown in Table 1, is the limited state. As we know, liberal democracies develop under the umbrella of the State historically (Dahl, 2001, p. 61). However, there is an important point, liberal democracy needs a state, but if the state is too powerful, democracy cannot work (Tilly, 2011). At this point, separation of law, protection of public interest, and distinction between the private and public sphere are important principles. In this way, power can be restricted. Rule of law is another important point to avoid defeat of rights of citizens across to state. Personal rights include the rights of protecting one's own body and conscience. Political rights include the right of participation, freedom of association, and others. The basis of economic rights is the right to property (Offe, 2011, p. 453). Accountability is very important to control the ruling party. Free and frequent elections are the most common control mechanism. Horizontal accountability is vital because it includes parliamentary opposition. Organized interest is an attempt to achieve their interests.

These principles are normative. States will be more democratic when they are closer to these principles. However, these principles are being threatened by the elections and new political campaign techniques because if people cannot attain correct information about political life, they are unable to make the best choices. It is possible to say that if political elites use the new techniques they can even define the concept of democracy itself. Yet, a democracy is meaningless unless it is defined by her citizens.

\section{2- The Problem of Democratization in Political Campaigns}

Scholars of liberal democracy give great attention to elections. They accept the importance of elections and election campaigns for a democratic country. However, some other critical scholars believe that liberal democracy assumes equality among citizens actually does not exist (Macpherson, 1979) and restricts the participation of ordinary citizens (Pateman, 1970). Some scholars of political communication think that these negative issues are also raised by political campaign techniques (Mancini \& Swanson, 1996; Mazzoleni \& Schulz, 1999; Negrine \& Papathanassopoulos, 1996).

Mancini and Swanson (1996) described these changes in a political campaign process as modernization of political campaigns and mention a modernization process concerning political campaigns worldwide. This process includes increased use of political advertising, the central role of the media, an increased role of technical experts, and growing budgets as the common themes used in campaign creation. This technique is an attempt to affect citizens under conditions of the modern world. The common points of these tools are prepared by experts and based on visual elements. Thus, political reality is defined by political actors and we believe and decide what we see. 
Table 2. The information in the table is based on Manicini and Swanson (1996), Mazzoleni and Schulz (1999), and Mayhew (1996).

\begin{tabular}{|c|c|c|}
\hline Elements & Traditional Campaigns & Modern Campaigns \\
\hline Advertising & Cheaper, low technology & $\begin{array}{lll}\text { Expensive, modern } & \text { high quality } \\
\text { techniques }\end{array}$ \\
\hline Media & Monitoring & $\begin{array}{l}\text { Effects on cognitive capacities, agenda } \\
\text { setting, impose own rule }\end{array}$ \\
\hline Technical experts & Party member, volunteer, strong ties to the party & Professional, paid, no ties to the party \\
\hline Budget & Limited & Very high \\
\hline
\end{tabular}

Media have an important role in this process. Media move away from an area of different political views. Thus, media have corruptive effects on the cognitive capacities of citizens. Blumler (1990) called this situation the "modern publicity process". The modern publicity process is a struggle to influence key political events and issues. There are results: Basically, political actors obtain more resources and energy for their media strategies. Second, pressure group activities will be more media-centric. Third, political decisions will be more mediated. Fourth, personalization dominates politics rather than issues that are difficult. Finally, media will determine the rules of modern publicity games. In brief, media is redefined doing politics and its content. In addition, media supports personalization.

Social differentiation brought on by modern life has changed party structures too. During the post-war period, especially the Western European party systems, there have been great transformations. Kircheimer (1966) defined this new party style as "catch all parties". Then, in the 1980s, Panebianco coined the concept of "electoral- professional parties". The most important point is that citizens have lost the ideological assumptions in this process. Thus, parties lost functions about their members' moral education. For new parties, everyone is a voter and parties try to attract members to take greater power. If parties want to take votes, they use marketing techniques and employ professionals. This structure is created by professionals defined by the Mayhew (1997) as "new public". In new public, professionals have a large influence in making decisions. Mayhew (1997) explained the basic problem: "In the twentieth century, the rise of technical, instrumental reason threatened to vitiate the process of public discussion" (4). In brief, the problem is that citizens are removed from making decisions.

In this process, the basic problem is the exclusion of citizens, as Bennett (1992) emphasized. In this new political area, media creates the reality; thus, content of the notions is defined by the media and actors that have been able to take part. My study is concentrated on this point. I assume that, in this new political environment, notions of democracy are defined by political actors and so it is important to analyse political leaders' discourse of democracy. Thus, I want to analyse the concept of democracy and how it can be found inconstant with normative meanings.

\section{Analysing the 2011 General Elections in Turkey}

In this study, political leaders' discourse on democracy in political campaigns is analysed by employing critical discourse analysis (CDA). My case study is the political rally speeches of the prime minister of Turkey, Tayyip Erdoğan, during the election cycle of 2011. I analyse rally speeches of the leader inside the scope of the 2011 political campaign for a month before the election. I analyse three normative principles in the speeches of Tayyip Erdoğan regarding liberal democracy: limited state, rule of law, and accountability. Analysing the political discourse is a broad study area and many studies have addressed this topic (Fairclough, 1996, 1998; Fairclough \& Wodak, 1997; Gastil, 1992; Van Dijk, 1997). The reason for choosing this method is the idea that political language is the social reality itself. Because as Fairclough (1996) noted, meanings of concepts can transform ideological common sense. It is a very important point for this study because if people accept the definition of concepts made by political elites, democracy cannot work. To analyse political discourse, we must think on three dimensions: description, interpretation and explanation (Fairclough, 1996).

Table 3. Dimensions and their content

\begin{tabular}{ll}
\hline Dimension & Content \\
\hline Description & Vocabulary, grammar and textual structures \\
Interpretation & Social context, instant status \\
Explanation & Ideological dimensions, social determinants \\
\hline
\end{tabular}

Note. Information based on Fairclough (1996). 
As we see in Table 3, analysing the political discourse is a complicated process. It must include social context and other dimensions with the language uses. In other words, social context as language is important. Hence, I will talk about political context before the elections of 2011 in Turkey and then analyse the discourse of democracy.

\subsection{Social Context in Turkey Before the 2011 General Elections}

Since the 1950s, democratization has been anticipated as a vital issue for Turkey's political actors. However, democratization reached importance after the 1990s, through the desire to join the EU, changing the international political environment after the cold war, and the growing demands of Turkish citizens. Thus, after the 1990s, the notion of democracy is one of the most widely used by the politicians in Turkey. After ten years, Turkey' political life gets a new face. Relations between the EU and Turkey changed after the 2000s. A new party called the Justice and Development Party (AKP) emerged after an economic crisis in Turkey. This new party came to power after its first general election in 2002. In the next two general elections, 2007 and 2011, the party was the ruling party.

Table 4. Vote rates of three major political parties in Turkey

\begin{tabular}{|l|l|l|l|}
\hline Party & 2002 Elections \% & 2007 Election \% & 2011 Election \\
\hline AKP & 35 & 46.58 & 49.83 \\
\hline CHP & 19 & 20.88 & 25.98 \\
\hline MHP & 8 & 14.27 & 13.01 \\
\hline
\end{tabular}

As you see in Table 4, AKP's votes increased during each of the three successive election campaign periods. We can explain these improvements as the traditional polarization of İslamic and republican groups in Turkey. Some people think that AKP is an İslamist party and they are in the face of secular republic values. This opposing group includes urban and educated people. The masses support the AKP because of the İslamic values in party politics (Yavuz, 2011). They live in both cities and rural areas. We can say that all of the speeches of the party leader Tayyip Erdoğan were based on this polarization

\subsection{Democracy Discourses in the Speech of Tayyip Erdoğan}

\subsubsection{Limited State}

Liberalism does not accept paternalism. In other words, liberalism never says what is "exactly through". Hence, the state should not decide on behalf of the people. When we look at the speeches of Tayyip Erdoğan, we can see the acceptance of a powerful state. He thinks that there is one absolute interest and it is the best for all society. It is not suitable for the liberal democratic limited state principle. He noted on July 142011 in Ankara, "The survival and the future of our state and republic depend on all of us to look the same. We all must want the same things" (Erdoğan).

As we see in the speech, one interest is defined for all society by Tayyip Erdoğan. However, the liberal democratic model is based on the different groups defending their interest. Actually, representation is about defending different groups' interests. Therefore, if there were only one interest in a society, representation would be meaningless. Tayyip Erdoğan's strong sense about a robust State can be seen at his overview of other parties. He marked the legal BDP political party as illegal. On June 102011 in Ağrı, he stated, "BDP is discriminatory, divided, and never in the face of these politics. Do not fight with these politics. Why? Because their objective is different (they are running after illegal politics)."

A strong state is a problem to improve a democratic culture. We can say that it is problematic when it was told by a political party leader addressed to the millions of people on a political rally speech.

\subsubsection{Rule of Law}

Rule of law is displayed in the individual rights of citizens. T. H. Marshall (2006) divided citizens' rights into three parts: civil rights, political rights and social rights. Civil rights are about the intellectual development facilities of citizens. In Turkey, civil rights are not developed because of the strong State. Political rights include the right of assembly, right of 
association etc. However, in the speeches of Tayyip Erdoğan, political rights can be seen as only the right to vote. On July 92011 in Gaziantep, Tayyip Erdoğan noted, "Let us give the CHP a democracy lecture on the ballot box. Go to the ballot with a loud voice and take the 12 representatives. Can the Gaziantep accomplish this? I believe you will."

In the speech, the success of the voters is seen as going to the ballot because their political rights involve voting. Other participation methods are not suitable for Turkey's democratic culture.

Social rights are very important to prohibit social inequalities. In Turkey, social rights are seen only as economic development. On July 62011 in Samsun, Tayyip Erdoğan noted, "National income 85 billion dollars of Turkey has increased 400 billion dollars in 4.5 years. In addition, Turkey is the sixth largest economy in Europe now. This is Turkey, country of the alteration."

As we see, economic development is the most important subject in Turkey's politics. However, social rights are about the improvement of the life quality of citizens. This not a problem in Tayyip Erdoğan's speeches. Purveying is a common method to help citizens. However, a systematic equality mechanism is not a policy issue.

\subsubsection{Accountability}

Accountability is a mechanism of inspection of the ruling party until the new elections. There are very complicated mechanisms such as constitutional courts, parliamentary debates, and questions, which could be entitled of horizontal mechanisms. This mechanism protects the citizens against cruel practices of the state. Tayyip Erdoğan excluded the horizontal mechanism. For him, accountability can occur only in the political rally. He noted on June 82011 in Elazığ, "Our complaint address is you. We share our happiness and joy, sadness and troubles, only with you."

The address of accountability is not parliamentary or other places. Political rallies are the basic mechanism of the accountability. The courage of a political leader can be seen at the political rally. Tayyip Erdoğan stated on July 62007 in Samsun, "I stand before you and I am ready to account. I have self-confidence to look your eyes into the faith."

For Tayyip Erdoğan, accountability is an issue of self-confidence. However, in liberal democracy, accountability is not seen as an individual activity. It must be implemented by institutions.

\section{Conclusion}

Liberal democracy is a common form of government all over the World. Turkey passed the multi-party system after 1950 and has tried to establish democratic institutions since then. The most important one of these institutions is free and frequent elections. Elections are seen as the most important tool of democracy in Turkey and even political participation is almost restricted on voting. The 1982 Constitution of Turkey particularly restricted citizen mobilization. For example, relations between civil society and political parties are restricted. Thus, in Turkey, citizens cannot mobilize, they can only vote. Next, political leaders confront citizens in the political campaign period more than another time. Leaders share their ideas about policies at campaign times; also, they benefit from concepts. The concept of democracy is one of the most widely used.

We see from our analysis that the discourse of political party leaders is shaped by this general perception of democracy. I claim that Tayyip Erdoğan's discourse of democracy is not sufficiently suitable for liberal democratic normative principles. The rights of citizens seen as voting and the duty of the State are defined as protecting and shaping them. Hence, to be a more democratic country, discourse on democracy in Turkey must be changed by political leaders first, because if the discourse of democracy is narrow, the democratic institutions of the country will not develop in accordance with democratic principles.

\section{References}

Beetham, D. (1996). Liberal democracy and the limits of democratization, in Prospects for Democracy, David Held (ed.). Oxford, UK: Blackwell Publishers, 55-73.

Bennett, W. L. (1992). White noise: The perils of mass mediated politics. Communication Monographs 59, 401-406.

Dahl, R. (2001). Demokrasi Üstüne, Betül Kadıoğlu (tr.), Ankara, Turkey: Phoenix.

Dryzek, J. S. \& Holmes, L. T. (2002). Post Communist Democratization Political Discourses across Thirteen Countries, Cambridge, MA: Cambridge University Press.

Fairclough, N. (1996). Language and power, New York, NY: Longman.

Fairclough, N. (1998). Critical discourse analysis, New York, NY: LongmanSartori.

Fairclough, N. \& Wodak, R. (1997). Critical discourse analysis. In Discourse as Social Interaction. Teun A. Van Dijk (ed.). London, UK: Sage. 258-284. 
Gastil, J. (1992), Undemocratic discourse: A review of theory and research on political discourse. Discourse and Society 3(4), 469-500. Giovanni, S_. (1996), Demokrasi Teorisine Geri Dönüş, T. Karamustafaoğlu ve Mehmet Turan (tr.), Ankara, Turkey: Yetkin Yayınevi. Lipset, M. S. (1981). Political man: The social bases of politics, Washington, DC: John Hopkins University Press.

Macpherson, C. B. (1979). The life and times of liberal democracy, Oxford, UK: Oxford University Press.

Mancini, P. \& Swanson, D. L. (1996). Politics, media and modern democracy: Introduction. Politics, Media and Modern Democracy. David L. Swanson and Paolo Mancini (eds.). Westprot, CT: Praeger. 1-26.

Marshall, T. H. (2006). Yurttaşlık ve Toplumsal Sınıflar, içinde Yurttaşlık ve toplumsal Sınıflar, Ayhan Kaya (tr.), T. H. Marshall- Tom Bottomore (ed.). İstanbul, Turkey: İstanbul Bilgi Üniversitesi Yayınları, s.1-56.

Mayhew, L. (2007). The new public: Professional communicaiton and the means of social influence. In The Political Communication Reader, Ralph Negrine \& James Stanyer (ed.). New York, NY: Routledge. 119-123.

Mazzoleni, G. \& Schulz, W. (1999), Mediatization of politics: A challenge for democracy? Political Communication 16(3), $247-261$.

Negrine, R. \& Papathanassopoulos, S. (1996). The Americanization of political communication. Press/Politics 1(2), 45-62.

Offe, C. (2011), Crisis and innovation of liberal democracy: Can deliberation be instituonalised? Czech Sociological Review, 47(3), 447472.

Özbudun, E. (2011), Otoriter Rejimler, Seçimsel Demokrasiler ve Türkiye, İstanbul, Turkey: Bilgi Universitesi.

Pateman, C. (1970). Participation and democratic theory, Cambridge, MA: Cambridge University Press.

Tilly, C. (2011), Demokrasi, (tr.) Ebru Arıcan, Ankara, Turkey: Phoenix.

Van Dijk, T. A. (1997). What is political discourse analysis. In Political Linguistics. J. Blommaert ve C. Bulcaen (ed.). Amsterdam, Netherlands: Benjamins. 11-52.

Yavuz, M. H. (2011). Erbakan'dan Erdoğan’a Laiklik, Demokrasi, Kürt Sorunu ve İslam, İstanbul, Turkey: Kitapyayınevi. 